\title{
Conversion of Waste Processing of the Vegetative Part of the Poplar by Indigenous Strains of Fungi of the Genus Trichoderma
}

\author{
Olga O. Mamaeva*, \\ Elena V. Isaeva and Tatyana V. Ryazanova \\ Reshetnev Siberian State University of Science and Technology \\ 31 Krasnoyarsky Rabochy, Krasnoyarsk, 660037, Russia
}

Received 22.10.2018, received in revised form 10.01.2019, accepted 25.04.2019

The article presents the results of a study of the impact of the enzyme complex strains M99-9 and K6-15 micro-peach fungi of the genus Trichoderma on a mixed substrate. It is established that in the process of biodegradation with strains K6-15 M99-9 in the substrate reduced content of extractives 2.1-2.4 times that of the polysaccharide is 1.5-1.8 times, and ligninase substances 1.2-1.4 times. This was an accumulation of up to 9-12\% of humic substances. The decrease in the mass of the substrate during the cultivation of the strain M99-9 was 17.3\%, and the strain K6 - 15-30\% less. The most productive on this substrate is strain K6-15. The growth of conidia within two weeks of cultivation for strain K6-15 was 16.6 $10^{8} \mathrm{CFU} / \mathrm{g}$ and strain M99-9-11,5·10 $\mathrm{CFU} / \mathrm{g}$. High yield of spores and formation of humic substances during cultivation of fungi of the genus Trichoderma makes it possible to use the vegetative part of a poplar as raw materials for receiving a biological product "Trichodermin" or humification of the soil.

Keywords: vegetative part of a poplar, leaves, buds, micromycetes, Trichoderma, biodegradability.

Citation: Mamaeva O.O., Isaeva E.V., Ryazanova T.V. Conversion of waste processing of the vegetative part of the poplar by indigenous strains of fungi of the genus Trichoderma, J. Sib. Fed. Univ. Chem., 2019, 12(2), 296-303. DOI: 10.17516/19982836-0127.

(C) Siberian Federal University. All rights reserved

* Corresponding author E-mail address: olga75_95@mail.ru 


\title{
Конверсия отходов переработки вегетативной части тополя аборигенными штаммами грибов рода Trichoderma
}

\author{
O.О. Мамаева, Е.В. Исаева, Т.В. Рязанова \\ Сибирский государственный университет науки \\ и технологий им. академика М.Ф. Решетнева \\ Россия, 660037, Красноярск, \\ пр. имени газеты «Красноярский рабочий», 31
}

Приведены результаты исследования воздействия ферментного комплекса итаммов М99-9 и К6-15 микроскопических грибов рода Trichoderma на смешанный субстрат. Установлено, что в результате этого воздействия в субстрате снижается содержание экстрактивных веществ в 2,1-2,4 раза, полисахаридов - 1,5-1,8 раза и лигниновых веществ - 1,2-1,4 раза. При этом отмечено накопление до 9-12\% гуминовых веществ. Убыль массы субстрата в процессе культивирования итамма М99-9 составила 17,3\%, а К6-15 - на 30 \% меньше. Наиболее продуктивным на данном субстрате является штамм К6-15. Продуктивность этого штамма за две недели культивирования составила 16,6 $10^{8}$ KOE/2, а штамма M99-9 - 11,5·10 KOE/2. Высокий выход спор и образование гуминовых вещуеств в процессе культивирования дают основания использовать вегетативную часть тополя в качестве сырья для получения биопрепарата для сельского хозяйства.

Ключевые слова: вегетативная часть тополя, опад, почки, микромицеть, Trichoderma, биодеструкиия.

\section{Введение}

Вегетативная часть растения (побеги, почки, листья) является уникальным источником природных соединений. Естественная возобновляемость древесных растений делает их неисчерпаемым сырьем для производства биологически активных веществ. В литературе имеются работы, в которых показана перспективность использования почек и листьев тополя в качестве источника для получения эффективных антибактериальных и противогрибковых лекарственных средств, белкового и провитаминного концентратов [1-3]. Высокой биологической активностью обладают экстракты почек тополя, содержащие в своем составе эфирные масла и флавоноиды [4-6].

В процессе зимне-весенней обрезки тополей образуется биомасса, состоящая из побегов с почками (50-60\%), летней - побегов с листьями (до 50 \%), которая может служить сырьем для извлечения биологически активных веществ [3]. Утилизация отходов после выделения экстрактивных веществ из вегетативной части тополя имеет важное экологическое и экономическое значение.

Биоконверсия как способ переработки растительных отходов в ценные продукты для сельского хозяйства на сегодняшний день является актуальной. С этой целью часто используют микроскопические грибы рода Trichoderma [7, 8]. 
На основе грибов рода Trichoderma получают биопрепарат «Триходермин», который используют в сельском хозяйстве для защиты растений от болезнетворных микроорганизмов. Введение в системы защиты растений данного препарата обеспечивает увеличение урожая основных культур и повышение качества сельскохозяйственной продукции, возможность отказа от использования ряда дорогостоящих пестицидов, оздоровление почвенной микробиоты, возможность переориентации хозяйств на производство экологически чистой продукции [9-11].

Следует отметить, что на основе микроскопических грибов рода Trichoderma возможно получать кормовые продукты для сельского хозяйства [12].

Цель настоящего исследования заключалась в установлении возможности использования смешанного субстрата, состоящего из листьев и почек тополя бальзамического, для культивирования грибов рода Trichoderma для получения биопрепарата для сельского хозяйства, что позволит в одном производстве объединить утилизацию как листьев, так и послеэкстракционного остатка почек тополя.

\section{Материалы и методы}

Объектом исследования служил смешанный субстрат, состоящий из опавших листьев (опад) и почек тополя, после удаления из них эфирных масел и извлечения этиловым спиртом экстрактивных веществ, в соотношении 1:1. Пробы для объекта исследования были отобраны с деревьев, произрастающих в окрестностях г. Красноярска, почки в апреле, а листья в сентябре 2016 г.

Для культивирования использовали два штамма грибов рода Trichoderma: T. aspirellum (М99-9), выделенный из почв Мининского лесного питомника в 1999 г. и штамм К6-15, выделенный из древесины кедра на территории дендрария Института леса им. В.Н. Сукачева СО РАН в 2015 г. из коллекции музея штаммов СибГУ им. М.Ф. Решетнева.

Субстраты увлажняли водой до $70 \%$, раскладывали в чашки Петри и стерилизовали в течение 30 мин в автоклаве при $1,01 \cdot 10^{5}$ МПа. Стерильный субстрат инокулировали споровой суспензией музейных штаммов Trichoderma с титром $1 \cdot 10^{6}$ спор на 1 г субстрата. Посевы инкубировали в термостате при $28{ }^{\circ} \mathrm{C}$ в течение 18 сут. Отбор проб осуществляли на 7-е, 11-е, 14-е, и 18-е сутки культивирования. Определение выхода конидий проводили с использованием камеры Горяева.

Для исследования состава субстрата до и после биодеструкции использовали методы, принятые в химии растительного сырья [13]. В исходных образцах определяли влажность методом высушивания, минеральные вещества - сжиганием навески растительного материала с последующим прокаливанием золы в муфельной печи. Содержание лигнина определяли по методу Кенинга с 72\%-ной серной кислотой. Гидролиз легкогидролизуемых полисахаридов проводили путем кипячения с $2 \%$-ной соляной кислотой, трудногидролизуемых полисахаридов $-80 \%$-ной серной кислотой при комнатной температуре. Количество моносахаридов в гидролизатах определяли эбулиостатическим методом. Общий азот определяли по методу Кьельдаля. Спирторастворимые вещества выделяли с помощью исчерпывающей экстракции этиловым спиртом, водорастворимые - с помощью 3-х часовой экстракции горячей водой. Состав минеральных веществ определяли методом рентгеновского флуоресцентного анали- 
за на спектрометре «Спектроскан». Гуминовые вещества выделяли трехкратной обработкой $0,1 \mathrm{~N} \mathrm{NaOH}$ при комнатной температуре и модуле 1:10. Убыль массы субстрата после биодеструкции определяли весовым методом по отношению к исходному субстрату до биодеструкции.

\section{Результаты и их обсуждение}

Изучение компонентного состава субстрата показало, что он может служить источником как макро-, так и микрокомпонентов, необходимых для развития микроорганизмов.

Установлено, что смешанный субстрат на 65,5 \% состоит из полисахаридов и лигниновых веществ, которые являются основным источником углерода для питания микроорганизмов (табл. 1).

Экстрактивные вещества представлены как водо-, так и спирторастворимыми компонентами, причем на долю веществ, экстрагируемых водой, приходится до 77 \% от их суммы, основными из которых являются подвижные углеводы. Следует отметить, что внесение в субстрат послеэкстракционного остатка почек привело к увеличению доли веществ лигниновой природы и снижению экстрактивных веществ по сравнению с опадом [11].

Источником азота могут выступать белки, содержащиеся в вегетативной части тополя. В пересчете от содержания общего азота количество белка составляет 6,4 \% от абсолютно сухого остатка (а.с.о.), из них 20 \% приходится на долю водорастворимого белка. Также субстрат может служить источником различных микроэлементов. Установлено, что в составе смешанного субстрата по сравнению с опадом, увеличивается доля элементов: фосфора, азота, калия, железа, магния, марганца и др., влияющих на интенсивность роста мицелия и спорообразования у грибов рода Trichoderma $[3,11]$.

Вторым этапом работы стало культивирование микроскопических грибов рода Trichoderma. Исследование показало, что на смешанном субстрате, так же как и на опаде листьев [11], более интенсивно процесс конидиегенеза протекал у штамма К6-15. На 11-е сутки выход колониеобразующих единиц (КОЕ) у штамма К6-15 в 1,7 раза превышал количество КОЕ штамма М99-9 и составил $13,1 \cdot 10^{8} \mathrm{KOE} /$ г. Продуктивность за две недели культивирования для штамма К6-15

Таблица 1. Химический состав вегетативной части тополя

Table 1. The chemical composition of the vegetative part of poplar

\begin{tabular}{|l|c|}
\hline \multicolumn{1}{|c|}{ Компонент } & Содержание в субстрате, \% а.с.с. \\
\hline Легкогидролизуемые полисахариды & 17,5 \\
\hline Трудногидролизуемые полисахариды & 13,0 \\
\hline Сумма полисахаридов & 30,5 \\
\hline Лигниновые вещества & 35,0 \\
\hline Вещества, экстрагируемые этиловым спиртом & 4,6 \\
\hline Вещества, экстрагируемые горячей водой & 15,5 \\
\hline Сумма экстрактивных веществ & 20,1 \\
\hline Минеральные вещества & 8,6 \\
\hline
\end{tabular}


составила $16,6 \cdot 10^{8} \mathrm{KOE} / г$, а для штамма М99-9 в 1,4 раз меньше. На 18-е сутки культивирования отмечалось снижение выхода конидий как у штамма М99-9, так и у штамма К6-15 [14].

Таким образом, полученные результаты дают основание утверждать, что через две недели культивирования биомасса смешанного субстрата по содержанию конидий соответствует биопрепарату. Причем добавление к опаду послеэкстракционного остатка почек тополя приводит как к увеличению (2,5-3 раза) выхода конидий, так и более глубокой конверсии субстрата [11], что, очевидно, связано со снижением доли экстрактивных веществ, оказывающих ингибирующее действие, в частности терпеноидов.

Об эффективности воздействия ферментативного комплекса исследуемых штаммов грибов рода Trichoderma судили по убыли массы субстрата в процессе культивирования: на 18-е сутки культивирования она составила для штамма М99-9 - 17,3 \%, для К6-15 - 12,5 \%, что в два раза выше, чем на опаде [11].

Результаты, свидетельствующие об изменении химического состава субстрата в процессе культивирования исследуемых штаммов, представлены в табл. 2 и 3. Для сравнения химического состава исходного субстрата и остатка после культивирования исследуемых штаммов производили пересчет полученных данных с учетом коэффициента убыли массы для каждого образца в процессе культивирования грибов в течение 18 сут. Количество каждого компонента, входящего в состав субстрата, рассчитано на единицу абсолютно сухого остатка.

Результаты исследования показывают, что культивирование данных штаммов приводит к изменению содержания всех компонентов субстрата.

Содержание водорастворимых веществ на 18-е сутки культивирования снизилось на $61 \%$ (М99-9) и 57 \% (К6-15). Количество веществ, экстрагируемых этиловым спиртом, в процессе культивирования грибов также изменилось. По окончании культивирования штаммов М99-9 и К6-15 их содержание снизилось на 50 и 37 \% соответственно.

Содержание легкогидролизуемых полисахаридов в субстрате после культивирования в течение 18 сут для штамма М99-9 уменьшилось на 45, а штамма К6-15 - 34 \% по сравнению с исходным субстратом (17,5 \%). Подвергаются изменениям и трудногидролизуемые полиса-

Таблица 2. Изменение химического состава субстрата в процессе культивирования штамма М99-9

Table 2. Changes in the chemical composition of the substrate during the cultivation of strain M99-9

\begin{tabular}{|l|c|c|c|c|}
\hline \multirow{2}{*}{ Компонент } & \multicolumn{4}{c|}{ Содержание, \% а.с.с. } \\
\cline { 2 - 5 } & 7 сут & 11 сут & 14 сут & 18 сут \\
\hline Легкогидролизуемые полисахариды & 17,1 & 14,4 & 11,0 & 9,6 \\
\hline Трудногидролизуемые полисахариды & 13,7 & 11,8 & 9,3 & 6,9 \\
\hline Сумма полисахаридов & 30,8 & 26,2 & 20,3 & 16,5 \\
\hline Вещества, экстрагируемые горячей водой & 12,3 & 11,5 & 7,5 & 6,1 \\
\hline Вещества, экстрагируемые этиловым спиртом & 4,6 & 3,9 & 3,3 & 2,3 \\
\hline Сумма экстрактивных веществ & 16,9 & 15,4 & 10,8 & 8,4 \\
\hline Лигниновые вещества & 34,7 & 35,5 & 31,1 & 24,9 \\
\hline Гуминовые вещества & 5,5 & 6,2 & 11,1 & 11,6 \\
\hline Минеральные вещества & 8,2 & 5,2 & 5,4 & 4,3 \\
\hline
\end{tabular}


Таблица 3. Изменение химического состава субстрата в процессе культивирования штамма К6-15

Table 3. Changes in the chemical composition of the substrate during the cultivation of strain K6-15

\begin{tabular}{|l|c|c|c|c|}
\hline \multirow{2}{*}{ Компонент } & \multicolumn{4}{c|}{ Содержание, \% а.с.с. } \\
\cline { 2 - 5 } & 7 сут & 11 сут & 14 сут & 18 сут \\
\hline Легкогидролизуемые полисахариды & 14,9 & 13,3 & 12,1 & 11,6 \\
\hline Трудногидролизуемые полисахариды & 12,1 & 9,4 & 9,1 & 8,2 \\
\hline Сумма полисахаридов & 27,0 & 22,7 & 21,2 & 19,8 \\
\hline Вещества, экстрагируемые горячей водой & 13,0 & 9,7 & 7,3 & 6,7 \\
\hline Вещества, экстрагируемые этиловым спиртом & 3,9 & 3,3 & 3,1 & 2,9 \\
\hline Сумма экстрактивных веществ & 16,9 & 12,9 & 10,4 & 9,6 \\
\hline Лигниновые вещества & 33,0 & 28,3 & 28,1 & 28,1 \\
\hline Гуминовые вещества & 5,2 & 5,8 & 7,2 & 9,1 \\
\hline Минеральные вещества & 7,7 & 6,2 & 5,5 & 5,3 \\
\hline
\end{tabular}

хариды. Их содержание в субстрате в результате биодеструкции штаммом К6-15 уже на 18-е сутки культивирования снизилось по сравнению с исходным субстратом на 37 \%, штаммом М99-9 на 47 \%.

Также следует отметить, что в результате биодеструкции происходит уменьшение количества минеральных веществ практически в два раза по сравнению с их содержанием в исходном смешанном субстрате.

Известно, что грибы рода Trichoderma являются продуцентами как целлюлолитических, так и лигнинолитических ферментов [15]. Установлено, что в процессе культивирования содержание лигниновых веществ в субстрате на 18-е сутки культивирования снижается на 20-30 \%. В процессе деструкции лигноуглеводного комплекса образуются гуминовые вещества (до $12 \%)$.

Таким образом, высокий выход спор и образование гуминовых веществ в процессе культивирования грибов рода Trichoderma дает основание к совместному использованию послеэкстракционного остатка почек и листьев тополя в качестве сырья для получения биопрепарата «Триходермин», который одновременно является структурообразователем почвы и гумифицирующим агентом.

\section{Выводы}

Результаты исследования позволяют сделать заключение о том, что почки после удаления из них экстрактивных веществ и опавшие листья тополя бальзамического могут служить субстратом для культивирования мицелиальных грибов. В процессе биодеструкции вегетативной части тополя грибами рода Trichoderma штаммами М99-9 и К6-15 утилизирована основная часть полисахаридов и экстрактивных веществ. Установлено, что содержание полисахаридов снизилось на 46 \% (М99-9) и 35 \% (К6-15), экстрактивных веществ - на 58 \% (М99-9) и 52 \% (К6-15).

Биопрепарат, полученный на основе смешанного субстрата, имеет более высокий (в 2,5-3 раза) титр спор по сравнению с опадом. Наиболее продуктивным при культивировании на данном субстрате является штамм К6-15 (1,7·10 КОЕ/Г).

$$
-301-
$$


Благодаря образованию гуминовых веществ (9-11 \%) биопрепарат может быть внесен в почву для гумификации. Для получения биопрепарата достаточно проводить культивирование в течение 14 сут.

\section{Список литературы}

1. Поляков B.В., Адекенов C.M. Биологически активные соединения растений Populus L. и препараты на их основе. Алматы: Гылым, 1999. 160 c. [Polyakov V.V., Adekenov S.M. Biologically active compounds of plants Populus L. and preparations based on them. Almaty: Gylym, 1999. 160 p. (In Russ.)].

2. Браславский В.Б., Куркин В.А., Жданов И.П. Антимикробная активность экстрактов и эфирных масел почек некоторых видов Popuius L. Растительные ресурсы 1991. Т. 27(2). С. 7781. [Braslavsky V.B., Kurkin V.A., Zhdanov I.P. Antimicrobial activity of extracts and essential oils of kidneys of some species Popuius L. Plant resources 1991. Vol. 27(2). P. 77-81 (In Russ.)].

3. Исаева Е.В., Рязанова Т.В. Состав, свойства и переработка отходов вегетативной части тополя после извлечения экстрактивных веществ. Сообщение 1. Химический состав твердых и жидких отходов. Химия растительного сырья 2012. № 3. C. 59-65. [Isaeva E.V., Ryazanova T.V. Composition, properties and processing of waste of vegetative part of poplar after extraction of extractive substances. Message 1. Chemical composition of solid and liquid waste. Chemistry of plant raw materials 2012. No. 3. P. 59-65. (In Russ.)].

4. Scaysbrook T., Greenway W., Whatley F.R. Relation of antimicrobial compounds present in poplar bud exudates to disease resistance by poplars. Z. Naturforsch 1992. Vol. 47. P. 197-200.

5. Isidorov V.A., Vinogorova V.T. GC-MS analyses of compounds extracted from buds of Populus balsamifera and Populus nigra. Z. Naturforsch. 2003. P. 355-360.

6. Wollenweber, E., Asarawa U., Scnillo D. A novel caffeic acid derivatives and other constituents of Populus buds excretion and propolis (bee-glue). Z. Naturforschung 1987. Vol. 42, No. 9/10. P. 1030-1034.

7. Алимова Ф.К. Trichoderma: таксономия и распространение. Казань: УНИПРЕССДАС, 2006. 260 c. [Alimova F.K. The Trichoderma: taxonomy and distribution. Kazan: UNIPRESS DAS, 2006. 260 p. (In Russ.)].

8. Кочерова А.В. Скрининг микромицетов - продуцентов лигнинолитических продуцентов ферментов. Молодые ученые в решении актуальных проблем науки: сб. ст. Красноярск. 2013. T. 2. C. 49-50. [Kocherov A.V. Screening of micromycetes - producers ligninolytic producers of enzymes. Young scientists in solving actual problems of science: collection of articles of Krasnoyarsk. 2013. Vol. 2. P. 49-50. (In Russ.)].

9. Пикозина М.А. Использование грибов рода Trichoderma для утилизации растительного сырья. Лесной и химический комплексы - проблемы и решения: сб. ст. по материалам всерос. науч.-практ. конф., посвященной 80-летию СибГТУ. Красноярск: СибГТУ, 2010. Т. 2. С. 6-9. [Pikosina M.A. The use of fungi of the genus Trichoderma for the recycling of vegetable raw materials. Forest and chemical complexes - problems and solutions: collection of articles on materials of vseros. science.-prakt. Conf. dedicated to the 80th anniversary of the Siberian state technological University. Krasnoyarsk: SibGTU, 2010. Vol. 2. P. 6-9. (In Russ.)].

10. Мамаева О.О., Исаева Е.В. Культивирование грибов рода Trichoderma на листьях. Современная биология: актуальные вопросы: ХХ междунар. науч.-практ. конф. С-Пб, 2016. С. 17-20. 
[Mamaeva O.O., Isaeva E.V. The Cultivation of fungi of the genus Trichoderma fungi on the poplar leaves. Modern biology: current issues: XX Intern. science.-prakt. Conf. C-Pb, 2016. P. 17-20. (In Russ.)].

11. Исаева Е.В., Мамаева О.О., Рязанова Т.В. Биоконверсия опавших листьев тополя бальзамического мицелиальными грибами рода Trichoderma. Журнала СФУ. Химия 2017. Вып. 10 (3). C. 381-389. [Isaeva E.V., Mamaeva O.O., Ryazanova T.V. Bio-conversion of the fallen leaves of the poplars mycelial fungi of genus Trichoderma. Journal of Siberian Federal University. Chemistry 2017. Vol. 10 (3). P. 381-389. (In Russ.)].

12. Рязанова Т.В., Чупрова Н.А., Литовка Ю.А. Биоконверсии вегетативной части топинамбура микро - и макроскопических грибов. Системы. Методы. Технологии 2016. № 1 (29). С. 147151. [Ryazanova T.V, Chuprov A.N., Litovka Y.A. Bioconversion of the vegetative part of Jerusalem artichoke micro - and macroscopic fungi. System. Methods. Technologies 2016. No. 1 (29). P. 147-151. (In Russ.)].

13. Рязанова Т.В., Чупрова Н.А., Исаева Е.В. Химия древесины. Красноярск: СибГТУ, 2012. 358 c. [Ryazanova T.V., Chuprova N.A,, Isaeva E.V. In wood Chemistry. Krasnoyarsk: SibGTU, 2012. 358 p. (In Russ.)].

14. Мамаева О.О., Русина А.С., Исаева Е.В. Культивирование грибов рода Trichoderma на вегетативной части тополя. Лесной и химические комплексы - проблемы и решения. Красноярск: СибГУ, 2017. С. 342-344. [Mamaeva O.O., Rusina A.S., Isaeva E.V. The cultivation of fungi of the genus Trichoderma on the vegetative parts of poplar. Forest and chemical complexes - problems and solutions. Krasnoyarsk: ShibGU, 2017. P. 342-344. (In Russ.)].

15. Рязанова Т.В., Чупрова Н.А., Лунева Т.А. Воздействие гриба рода Trichoderma на лигнин коры древесных пород. Катализ в промышленности 2014. № 6. C. 64-70. [Ryazanova T.V., Chuprova N.A, Luneva T.A. Influence of the fungus of the genus Trichoderma on lignin of the bark of tree species. Catalysis in industry 2014. No. 6. P. 64-70. (In Russ.)]. 